\title{
Human Dignity: Between the Existentialist and the Essentialist Approaches
}

\author{
GRZEGORZ HOLUB \\ The Pontifical University of John Paul II, ul. Kanonicza 9, 31-002 Krakow, Poland \\ Email: grzegorz.holub@upjp2.edu.pl
}

\begin{abstract}
Human dignity is an important part of Western culture, which has spread over the world, and theses on it can be considered in and applied to various spheres of human life and whole societies. In this paper, a selected aspect of dignity is undertaken, namely, how we get to know and understand dignity. This aspect is considered by personalists and other philosophers interested in shedding some light on human dignity. Two approaches to the matter are adopted and contrasted: existentialist and essentialist. The former stresses how dignity is discovered and how it exists in its very essence, via experience and phenomenological insight. The latter concentrates on the description of personal characteristics and other relevant factors, which result in a thesis on dignity. In the conclusions, the author points out that these two approaches should not be considered as alternatives contending with each other but rather narratives complementing one another.
\end{abstract}

Keywords: human person, dignity, existentialist stance, essentialist stance, personalism

\section{INTRODUCTION}

Human dignity seems to constitute the cornerstone of the Western civilisation, which animates many issues of the contemporary world. That is why respective discussions are long-standing and complex. We can notice tendencies looking for sources of this category as well as positions offering various explanations. Usually, arguments proposed here have historical, religious and philosophical characters (Barilan 2012: 23-92; Rosen 2012). As to the latter, they were basically formulated in the modern and the contemporary philosophy; although some premises of dignity can be also found in the ancient and medieval philosophy. Furthermore, we encounter staunch defenders of human dignity (e.g. Kass 2002; Fukuyama 2003: 149-177) and its decisive critics (e.g. Singer 1993: 88-89; Birnbacher 2005: 50-55). They interact with each other in various spheres of human activities, including socio-political and legal debates as well as ethical and bioethical ones. It seems that the notion of dignity still keeps its prominent position and, moreover, remains intriguing (see, e.g. Düwell, Braavig, Brownsword, Mieth 2014). At any rate, it is open for further elaboration and modification. Preliminarily, human dignity and its consequences will be understood in the following way: 'Human dignity is a moral property innate to all humans. Because all humans are equally human, there is no single person whose dignity is superior or inferior to any other. Because 
humans never metamorphose to something else, there humanness is permanent. Because human dignity is derived only from this humanness, human dignity is irrevocable. All humans are equally expected to respect the human dignity of each other; all people should be treated equally in matters of human dignity.' (Barilan 2012: 93)

In this paper, we are going to concentrate on a specific aspect of human dignity, which is present in the philosophy of the human person advanced by personalists. ${ }^{1}$ The latter consider it as an essential notion and put it in the centre of their attention. However, it is hard to find a good explanation of it in their works. It seems that they assume that the grasping of dignity is obvious and, associated with it, moral imperatives are generated in a straightforward manner. This is far from certain and if dignity is to be considered a viable category, better epistemological explanations are necessary. Of course, the paper does not aspire to solve all these problems but tends to sketch a new approach in dealing with them. Thus, we are going to outline some of the main theses on dignity present in the personalist philosophy and undertake a new way of advancing them, drawing upon resources borrowed from thinkers who talk about dignity but do not directly subscribe to this philosophical current. To be more precise, we want to formulate and juxtapose two versions of human dignity: existentialist stance versus essentialist stance. ${ }^{2}$ By the end of the paper, we will try to elaborate on their relationship and show how their balanced association can help in a better understanding of the phenomenon of human dignity itself.

The method applied in the paper involves analysing ideas of various adherents of the human dignity and their assessment. It also tends to show a new area of investigation of dignity, which joins various approaches to it. The whole of the following investigation can be considered as belonging to philosophical anthropology and axiology.

\section{DIGNITY - THE EXISTENTIALIST APPROACH}

The existentialist approach concentrates on the existence of human dignity as a special phenomenon. It usually does not offer an extensive explanation of it, but conveys some basic information concerning dignity. The latter is understood as a fundamental attribute and quality of the human being, which is given but must also be discovered (Wojtyla 2002: 112). Thus, a human being endowed with dignity possesses a special axiological status, a special value and hence cannot be treated as a mere means to something else. What is important here is to point out that only human beings are considered as possessing such a special position in the world. In the personalist philosophy, this position is associated, in the first place, with the kind of entity the human being is. ${ }^{3}$

1 There are many kinds of personalisms. In this paper, we are going to limit our considerations to selected versions of personalisms connected simultaneously with phenomenological and ontological traditions.

2 Although the paper is not a part of investigations typical of the existentialist philosophy, a dialogue concerning the character of this philosophy, which took place between J.-P. Sartre and M. Heidegger, can be here instructive. The former argued that existence should precede essence. The latter pointed out that even such a reversal of the Platonic metaphysical order is still a kind of metaphysics. (Heidegger 2000: 90) Thus, our investigations on the existentialist and essentialist approach to dignity are parts of the Western metaphysics, even if they concern the human person in her uniqueness.

3 Human dignity is always considered as an intrinsic value. For instance, Yechiel Barilan in his definition cited above set it forth clearly (Barilan 2012: 93). However, Michael Rosen claims that 'human dignity is only one (if extremely important) form of dignity. Perhaps plants have an intrinsic value to be defended too' (Rosen 2012: 19). Even if it is true that not only human beings have intrinsic values, only they can be accredited with a special value, namely, dignity. 
'Josef Seifert claims that value called "dignity" is an ultimate and irreducible phenomenon which cannot be defined properly speaking but can only be unfolded and brought to evidence' (Seifert 1997: 98). This philosopher, associated with a classical phenomenology, provides some explanation of this important category. He claims that it amounts to an objective and intrinsic value, that is, it is not someone's subjective projection but has an in-dwelling positive importance (Seifert 1997: 96-97). As any other value, human dignity has a strong impact on human individuals. Seifert maintains that it does not leave us in our arbitrariness but imposes a call to respect it, to respond to it, to show interest in it (Seifert 1997: 96). Thus, we have some description of value and dignity in particular; it signals its character and reference. But still, we lack its better characterization.

Similar claims concerning dignity can be found in other personalists' arguments. For instance, the Polish philosopher Andrzej Szostek maintained that dignity is given in a fundamental cognition and this amounts to a kind of experience too. This cognition-experience is given amid cognition of other features typical of human life and it presupposes - as Szostek puts it - a certain degree of maturity of the subject. In other words, human dignity is a part of our everyday life, especially when we meet human persons, and requires a fair amount of psychological equilibrium, including our ability to experience and recognize values in their hierarchy. Also, human dignity bears moral imperatives on the side of those who experience it and, at the same time, brings with it a justification of these imperatives (Szostek 1998: 49).

Looking for the philosophical roots of such propositions concerning human dignity, we can point to classical phenomenology. Although personalism cannot be wholly identified with any particular offspring of phenomenology, some of its versions draw to some extent on phenomenological procedures and conclusions. For example, Dietrich von Hildebrand singled out an ontological value, which determines the preciousness of the human person and is realized in the human life. It is not possible for a given person to lose such a value. In other words, it is strictly associated with the ontological structure of his being (von Hildebrand 1952: 137). As to a mode of how such a value is given epistemologically, phenomenological insight and intuition must be given privileged roles. Using the same methods, Max Scheler speaks about 'the persons's value-essence' (Scheler 1973: 487-489), which can reflect his special axiological position. The German philosopher is convinced that this essence goes beyond what we know about the person in the light of empirical, historical and psychological investigations. Moreover, it is the basis of all other understandings of the person. Therefore no inductive procedure can reach this value-essence. As Scheler maintains, it is given as if from 'on high' meaning by that 'the light streaming from the intuition of the person's essence onto all of his empirical experiences that raises the cognition of him <...>' (Scheler 1973: 488). Putting aside differences between the mentioned phenomenologists, we can conclude that human dignity is given directly and intuitively via an act of phenomenological insight. It is at the basis of any other significance and value ascribed to a human person.

However, this existential and experiential character of human dignity still demands further explanation. We need to shed some more light on it especially when we are about to apply it to particular cases or determine in detail what it means to infringe on or respect human dignity. In this regard, let us point to a telling example provided by the Polish personalist philosopher Tadeusz Styczen. Two people A and B are to visit their friend C in a hospital. The latter is seriously ill and unaware of it, hence A and B wonder what they 
should do in the situation. A claims that the whole truth about C's health should be revealed in front of him, whereas B holds the opposite opinion, namely, that this truth should not be revealed at all. Both friends want to act for the good of their common friend but they differ as to what to do in practice (Styczen 2012: 328-330). This divergence does not concern the applicative level, as it may seem prima facie, but it takes its root from differing understandings of the good of the patient himself. Within our analysis, it means that human dignity can be given in the axiological experience, and acknowledged as such, but when it comes to how to respect it, various, even opposing ideas can be proposed. Correspondingly, here there is not a problem with application but with the understanding of human dignity itself, and hence we need to know more about it.

There are some personalists who open up a way to further clarification of this important phenomenon. For instance, Karol Wojtyla claims that there is no pure act of experience. Whenever the latter is given, it is always associated with a kind of cognition; as he puts it, 'any experience is at the same time a kind of understanding' (Wojtyla 1994: 52). This thesis can have its reference to human dignity and its two interpretations can be advanced. Firstly, a narrow interpretation, according to which only our experience of the essence-value of human being is given as a reality to be further explored cognitively in a phenomenological insight. Secondly, a broader interpretation that the essence-value with its ways of manifestation and supporting reasons are objects of the experience as well as cognition. In this latter approach, we are to investigate human dignity in a broader context, including empirical factors, which Scheler considers secondary. Employing such an approach can direct our attention to an essentialist position on human dignity.

\section{DIGNITY - THE ESSENTIALIST STANCE}

This approach to human dignity is focused on features, which manifest the phenomenon as well as reasons supporting its existence. In this position we are not so much concerned with the way of how dignity exists and what kind of existence it is. Thus, we are not dealing with the intuition of dignity and its intuitive obviousness. Of course, we assume that it is an existing and real phenomenon that has a strong impact on our decisions and undertakings. Moreover, our interest is not limited to essential features of dignity, which are usually subjects of phenomenological investigations. We take into account many other dependencies and traits, which can be considered accidental and non-essential by phenomenologists. Thus, the essentialist position understands human dignity in broader terms.

The essentialist approach is employed every time we try to describe elements revealing human dignity and to point to reasons backing its existence. At times, the former is interchangeable with the latter. However, this approach can bring with it some uncertainties and ambiguities and thus can equally be helpful and distracting in our investigations. As to the latter, we can give one example. For Immanuel Kant entertaining dignity means possessing a positive feature, namely, autonomy. Human beings are creatures who possess a capacity for respecting the moral law of which they themselves are the authors. This capacity is strictly associated with the possession of reason and is even a manifestation of their rational nature. Thus - as one of Kant's commentators claims - 'the fundamentally valuable thing in the universe is a rational being, a person - or, more precisely, rational nature in a person' (Wood 2008: 94). Consequently, human beings cannot be treated only as means but always as ends in themselves (Kant 2011: 38). In this position, it is easy to identify dignity with autonomy to such an extent that only the latter does matter. Then, we 
can consider dignity as a 'useless concept' which is reducible to respect for autonomy, as Ruth Macklin maintains. ${ }^{4}$

An interesting account of human dignity is advanced by the American scholar George Kateb. He stresses the dignity of the human species as well as the dignity of the human individual. A main characteristic, which plays its decisive role here, is uniqueness. Thus, the human species is unique among other species which inhabit the earth. Kateb puts it this way, 'all other species are more alike than humanity is like any of them; chimpanzee is more like an earthworm than a human being, despite the close biological relation of chimpanzees to human beings. The small genetic difference between humanity and its closest relatives is actually a difference in capacity and potentiality that is indefinitely large, which actually means that it can never by fully measured. Only the human species is, in the most important existential respects, a break with nature and significantly not natural' (Kateb 2011: 17). Correspondingly, we can claim that any particular human being possesses dignity because he is unique among not only other non-human creatures but also among human individuals as well. People differ among themselves as to their identity and this is caused by their basic dispositions. Kateb maintains that 'human identity rests on unique traits and attributes, which make human beings capable of commendable works and ways of being, but also of wrongdoing of every kind and in every degree' (Kateb 2011: 18).

Our specifically human characteristics that make us unique consist in mental and volitional faculties. They give us a qualitatively different insight into an existing world and into ourselves. We can gain an extensive knowledge about reality and also form a unique, personal approach to that reality, say, aesthetic and spiritual. Basically there is no other creature that can inherit this strictly human legacy on the moment of our departure from this world. As Kateb puts it, 'before humanity perish we could not pass on to any other species, not even our closest relatives, our knowledge and appreciation of nature' (Kateb 2011:24).

In fact, the special position of the human being in this world stemming from his unique traits is well manifest when we compare him to other non-human creatures, especially to animals. Kateb points out that only humans exist to themselves and are self-conscious. Animals exist but are not conscious of that fact. Also language plays here an essential role. 'Language - as Kateb maintains - is what nature lacks and what humanity has; where language is lacking, a thing or creature cannot exist to itself. Only a mind can say, I exist, can describe itself, try to understand itself, $<\ldots>$ and try to understand and appreciate what exists around. Only humanity can speak about the rest of nature and for it' (Kateb 2011: 117).

Thus, human beings possess an outstanding value, i. e. dignity, because of special endowments. They have non-natural or extra-natural characters, and as a result a human being can employ a set of unique attitudes toward the world. He also proves, in many ways, that he does not wholly belong to this world. For instance, despite his embodied condition, he can live in the world of abstract ideas and projects (e.g. mathematics and philosophy). ${ }^{5}$ Kateb offers an interesting observation concerning those non-natural characteristics; it goes in the following way, 'the irony is that only by non-natural traits and attributes, which are uniquely

${ }^{4}$ Macklin points out that dignity 'is nothing more than a capacity for rational thought and action, the central features conveyed in the principle of respect for autonomy' (Macklin 2003: 1419-1420).

5 Of course, in the longer run those ideas and projects can work for the sake of embodied existence. A well-known environmental philosopher Holmes Rolston III puts it this way, 'humans are remarkable among all other species in their capacities to process thoughts, ideas, symbolic abstractions figured into interpretative gestalts with which the world is understood and life is oriented' (Rolston III 2009: 136). 
human, is the human race able to serve nature: to record its history, to know it, and to appreciate and admire it. But also by these same traits and attributes, the human species has given repeated praiseworthy demonstration of its non-natural stature apart from its service to nature' (Kateb 2011: 115).

\section{BETWEEN THE EXISTENTIALIST AND THE ESSENTIALIST POSITIONS}

The first proof that human dignity exists is that a human being recognizes it as such and formulates respective narratives concerning it, namely, concepts of it. ${ }^{6}$ Because they are several, we can approach human dignity in various ways, as the above analyses indicate. The existential stance tries to explore this phenomenon at its very source stressing the experiential character of it. As can be seen, this is the important manner of exploring dignity as an extra-empirical and axiological reality. If we treat dignity as the value, which sheds some light on further aspects of human life, we can always claim that it transcends those facets and does not exhaust itself in them. Some personalists, especially those metaphysically-oriented (but also employing a phenomenological method), will consider human dignity as an ontological value, that is, the value associated with the kind of being the human person is. This we can call the dignity of personhood. ${ }^{7}$ However, the discovery of this version of dignity does not provide us with a good rationale; as mentioned above, we still lack epistemological resources to describe it in an adequate way. At any rate, the existentialist stance must be complemented.

The essentialist concept of dignity offers a more specific understanding of this category. It stresses various contents of the phenomenon, which can also deliver some answers on its rationale. ${ }^{8}$ However, this stance describes human dignity on the level of specific human features and functions. It informs us of the preciousness of humanity when human personality, interpersonal and other relationships are taken into account. Here, the thesis about dignity seems to stand not at the beginning (as it is the case in phenomenological approach) but at the end of the investigative process. In the typology developed by the Polish personalist Adam Rodzinski, the essentialist stance concerns the so-called dignity of personality (Rodzinski

6 The formulation of the notion of human dignity, on the personal level, is preceded by a basic experience of our own preciousness. Holmes Rolston III points also to an evolutionary explanation of this very first moment claiming that, 'humans evolved to have dignity when they evolved to be able to entertain the concept of dignity (and to acknowledge dignity by way of respect, recognition, courtesy), as chimpanzees cannot' (Rolston III 2009: 147).

In the personalist position it is widely claimed that the dignity of personhood is inborn, that is, it is not an object of endowment by any institution or individual; also, it cannot be removed or annulled by anyone or anything. Daniel Sulmasy calls this kind of dignity 'intrinsic dignity', and explains it in the following way, 'intrinsic dignity $<\ldots>$ is the intrinsic value of entities that are members of a natural kind that is, as a kind, capable of language, rationality, love, free will, moral agency, creativity, aesthetic sensibility, and an ability to grasp the finite and the infinite' (Sulmasy 2009: 477).

8 In the existentialist position, associated with the phenomenological approach, the rationale for human dignity is entirely contained in the phenomenon itself. Dignity, given in experience, is grasped in its important features and relations. Basically, we are concerned here with what is essential in this phenomenon. In general, it is a part of the phenomenological attitude (see Scheler 1979: 380-381). In the essentialist stance in turn, we look at manifestations of the phenomenon in all its richness, and sometimes in contrast with other similar phenomena (e.g. values of other creatures). These manifestations give us not only a pure content but also suggest some presuppositions, including ontological ones. Thus, talking about the content of dignity gives us some rights to talk about its reasons and point to some explanations. 
1968: 43-49). ${ }^{9}$ It reveals itself on the level of personal features, which are changeable, prone to modifications stimulated by the outer environment or by a given subject; which can be improved or worsened. ${ }^{10}$ Compared with the dignity of personhood, the dignity of personality can be easily known and described. Nevertheless, we cannot limit our claims on dignity to the latter concept. ${ }^{11}$ The reason for this is that it does not concern all stages of human life. For instance, a human embryo does not possess a personality understood as a set of acquired psychological features and hence we have no premises to talk about his dignity of personality. Similar examples can be delivered by extreme states connected with the end of human life like deep dementia or advanced stages of Alzheimer's disease. Thus, identifying dignity of personality with dignity as such, we run the risk of excluding from its domain vital stages of human existence.

In fact, we need these two approaches to human dignity. They are not opposed to each other but rather complementary. There are some reasons supporting this thesis. Firstly, the dignity of personhood is not only available within the phenomenological insight but tends to shed its light on and encompass all spheres of personal existence. Thus, this fundamental dignity finds its revelation in personal characteristics, even if it is always partial and incomplete. Hence, secondly, the dignity of personality participates in the dignity of personhood; in a sense, it is its prolongation. All in all, they are interrelated and complementary. ${ }^{12}$ When we lack signs of dignity of personality, we can base our respective discourse on the concept of dignity of personhood. When we need to apply the notion of dignity to particular cases, basically we will draw on dignity of personality.

In the epistemological order, there is a twofold dependency concerning human dignity. For philosophers who basically adhere to the phenomenological method, dignity of personhood is given immediately and brings with it a high level of certainty; we can call this a 'from on high way'. However, for philosophers who do not subscribe to the phenomenological method in a strict sense (but nevertheless can be considered phenomenologists in a broader sense), dignity is mainly given via personal characteristics, as if 'from below'. Thus, through

9 Thus, we have dignity of personhood and dignity of personality; Rodzinski also introduces a third kind of dignity, namely, someone's feeling of dignity (see Rodzinski 1968: 43-49). The latter does not play any essential role in our analyses. Thus, we are not going to concentrate on it. Similar kinds of dignity are advocated by Patrick Lee and Robert George too; they point to personal dignity, dignity that is manifestation and actualization of typically human characteristics, and one's sense of dignity (see Lee, George 2008: 173-174).

${ }^{10}$ Dignity of personality, which Sulamsy also calls 'inflorescent dignity', can relatively easily be grasped by an outer observer. Thus, it can result in social recognition or a so-called 'attributed dignity' (Sulmasy 2011: 475-476).

11 We can point to a further relationship between these two versions of dignity. Dignity of personality can be considered in itself, and - although it is changeable and gradual in various individuals - it sets forth to a certain degree human greatness and preciousness. However, it also leads us to the discovery of dignity of personhood. In a sense, the latter is reflected in the former. Then, dignity of personhood is not discovered at the outset of our investigation but by its completion.

12 Of course, some philosophers talking about human dignity mean only dignity of personality. Then, they concentrate on and value only personal characteristics, and shun dignity of personhood. For instance, Helga Kuhse, adhering to naturalist stance on the human person, reasons as follow: 'If one takes this approach, then one is not saying that human life has sanctity, but rather that rationality, the capacity to be self-aware, moral or purposeful, and so on, have "sanctity" (Kuhse 1987: 212). In the personalistic position, which assumes both ontological and phenomenological approaches to the person, such a reduction is not accepted. 
their unfolding and interaction with others we acquire admiration and respect for their author. ${ }^{13}$ Both of these epistemological ways can be useful in a course of thorough penetration of this important phenomenon. We can treat them as tools enabling us to explore the integral picture of human dignity, namely, its 'background' and 'foreground'.

\section{CONCLUSIONS}

Human dignity is an extremely important issue in many anthropological, ethical, bioethical, and other debates. At the same time, it is a phenomenon which is complex and difficult to explore. To understand dignity better, we need to conduct a multidimensional investigation on it, and this amounts to a more advanced inquiry into the reality of the human person himself. Respective investigations have oscillated between intuitive and axiological datum, and psychological (personality-related) and ontological factors. Hence, two possible extremes should be avoided, namely, identification of dignity with a purely subjective experience and feeling, which is hard to prove and communicate inter-subjectively, on the one hand; and on the other hand, limiting dignity to a derivative of a set of psychological and other empirical qualities, which can lead us to the relativization of the axiological specificity of the human being and even its complete loss. Further analyses and explorations should not be conducted one-sidedly but should take place within the compass of both the existentialist and essentialist approaches to this vital matter. ${ }^{14}$

Received 12 December 2018

Accepted 20 May 2019

\section{References}

1. Barilan, Y. M. 2012. Human Dignity, Human Rights, and Responsibility, Cambridge (MA) and London: The MIT Press.

2. Birnbacher, D. 2005. 'Human Cloning and Human Dignity', Reproductive BioMedicine Online 10 Supplement 1: 50-55.

3. Clarke, N. W. 1993. Person and Being. Milwaukee: Marquette University Press.

4. Düwell, M.; Braavig, J.; Brownsword, R.; Mieth, D. (eds.). 2014. The Cambridge Handbook of Human Dignity: Interdisciplinary Perspectives. Cambridge: The Cambridge University Press.

5. Fukuyama, F. 2003. Our Posthuman Future. Consequences of the Biotechnology Revolution. London: Profile Books.

6. Heidegger, M. 2000. 'Letter on Humanism', Global Religious Vision 1/I: 83-109.

7. Kant, I. 2001. Groundwork of the Metaphysics of Morals. Cambridge: Cambridge University Press.

8. Kass, L. 2002. Life, Liberty and the Defence of Dignity. The Challenge for Bioethics. New York and London: Encounter Books.

${ }^{13}$ The discovery of dignity can proceed in a way similar to Norris Clarke's description of revelation of personhood for a given human subject. He claims that 'to actualize itself, make it luminously present to itself in act, it must first open itself to the world of others, be waked up by their action on it and its own active response $\langle\ldots .$. . Only then, through the mediation of the other, can it return to itself, to discover itself as self-conscious "I", as this unique human person' (Clarke 1993: 65).

${ }^{14}$ The conclusions of the paper are in some ways connected to the ethical project proposed by Tadeusz Styczen. He describes how moral norms are constituted drawing on resources offered by the phenomenological-ontological personalism. He points to two stages. Firstly, a subject experiences the value, human dignity and this experience bears a subjective imperative to respect the person. This instance has an existential character. Hence, secondly, a reference to an objective structure of the person endowed with personal dignity is necessary. And this objective structure of the human being determines and specifies the content of the experientially and subjectively given imperative. Thus, ethics is strictly associated with philosophical anthropology (Styczen 1997: 177-178). In this position, a complementarity between the existentialist and the essentialist approaches is also vital and indispensable. 
9. Kateb, G. 2011. Human Dignity. Cambridge (MA): The Belknap Press of Harvard University Press.

10. Kuhse, H. 1987. The Sanctity-of-Life Doctrine in Medicine: A Critique. Oxford: Oxford University Press.

11. Lee, P.; George, R. P. 2008. 'The Nature and Basis of Human Dignity', Ratio Juris 21(2): 173-193.

12. Macklin, R. 2003. 'Dignity Is a Useless Concept', British Medical Journal 327: 1419-1420.

13. Rodzinski, A. 1968. 'U podstaw kultury moralnej', Roczniki Filozoficzne 16(2): 43-49.

14. Rolston III, H. 2009. 'Human Uniqueness and Human Dignity: Persons in Nature and the Nature of Persons', in Human Dignity and Bioethics, eds. E. Pellegrino, A. Schulman, Th. W. Merrill. Notre Dame: Notre Dame University Press, 129-153.

15. Rosen, M. 2012. Dignity. Its History and Meaning. Cambridge (MA): Harvard University Press.

16. Scheler, M. 1973. Formalism in Ethics and Non-Formal Ethics of Value. A New Attempt toward the Foundation of an Ethical Personalism. Evanston: Northwestern University Press.

17. Scheler, M. 1979. 'Phänomenologische Einstelung', in Schriften aus dem Nachlass, Vol. I, Zur Ethik und Erkenntnislehre, ed. M. Scheler. Bern: Francke Verlag, 380-381.

18. Seifert, J. 1997. What Is Life? The Originality, Irreducibility, and Value of Life. Amsterdam and Atlanta: Rodopi.

19. Singer, P. 1993. Practical Ethics. New York: Cambridge University Press.

20. Styczen, T. 1997. 'Etyka', in Leksykon filozofii klasycznej, ed. J. Herbut. Lublin: Towarzystwo Naukowe KUL, 176-180.

21. Styczen, T. 2012. Etyka niezalezna? Lublin: Towarzystwo Naukow KUL.

22. Sulmasy, D. 2011. 'Dignity and Bioethics: History, Theory, and Selected Applications', in Human Dignity and Bioethics, eds. Pellegrino, Schulman, Merrill, 469-501.

23. Szostek, A. 1998. Wokol godnosci, prawdy i milosci. Rozwazania etyczne. Lublin: Wydawnictwo Katolickiego Uniwersytetu Lubelskiego.

24. Von Hildebrand, D. 1952. Christian Ethics. New York: McKay.

25. Wojtyla, K. 1994. 'Osoba i czyn', in Osoba i czyn oraz inne studia antropologiczne, ed. K. Wojtyla. Lublin: Wydawnictwo Towarzystwa Naukowego Katolickiego Uniwersytetu Lubelskiego, 43-344.

26. Wojtyla, K. 2002. L'uomo nel campo della responsabilità. Trans. L. Crisanti. Milano: Bompiani.

27. Wood, A. W. 2008. Kantian Ethics. New York: Cambridge University Press.

\title{
GRZEGORZ HOLUB
}

\section{Žmogaus orumas: tarp egzistencialistinio ir esencialistinio požiūrių}

\begin{abstract}
Santrauka
Žmogaus orumas yra svarbi visame pasaulyje paplitusios vakarietiškosios kultūros dalis, todèl ši tema gali būti analizuojama ir taikoma ịvairioms žmogaus gyvenimo sritims ir skirtingoms visuomenems. Straipsnyje aptariamas orumas - kaip mes ji atpažįstame ir suprantame. Tai analizuoja skirtingi žmonès ir filosofai, kuriems svarbi žmogiškojo orumo tema. Pasirenkami ir supriešinami du požiūriai - egzistencialistinis ir esencialistinis. Pirmajame pabrěžiama kaip orumas atrastas ir kaip jis egzistuoja remiantis patirtimi ir fenomenologine j̨žvalga. Vèliau susitelkiama ties asmeninių savybių ir kitų tiesiogiai susijusių veiksnių aprašymu, kuris baigiamas tezėmis apie orumą. Išvadose autorius pabrèžia, kad šie du požiūriai turètų būti laikomi ne tiek viena su kita kovojančiomis alternatyvomis, o labiau vienas kitą papildančiais pasakojimais.
\end{abstract}

Raktažodžiai: žmogus, orumas, esencialistinè pozicija, personalizmas 